\title{
REPORT OF AN EXCURSION TO THE PORTMADOC AND CRICCIETH DISTRICT OF SOUTH-EAST CARNARVONSHIRE.
}

APril 5TH TO IITH (EASTer), igr 2.

By W. G. Fearnsides, M.A., F.G.S., Director of the Excursion.

April $5 \mathrm{TH}$.

Despite the inconvenience caused by the coal strike, a party, some forty strong, had reached Criccieth, and were assembled outside the Marine Hotel to join the carriages which were to take them to Portmadoc on the morning of Friday, April 5th. A pleasant drive brought us in about half an hour to the eastern side of the town of Portmadoc, and we began work by examining the classical locality of Ynys Towyn. The Tremadoc Slates were first examined, and quite soon, from the highest beds of this series, numerous fragments and some good specimens of Angelina sedgwickii, Asaphellus homfrayi, and Bellerophon arfonensis were brought to light. Animal remains were probably intermingled with most of the mud of which this division of Tremadoc Slates was formed, but in most exposures they seem to have been obliterated by the cleavage. Here at Ynys Towyn the unyielding mass of overlying grit has protected the slaty rocks from excessive distortion by the cleavage; and from the foot or two of mudstone which immediately underlies the Ordovician unconformity fossils can be broken out. The Ordovician grit and its flaggy partings were next examined but yielded no sign of a fossil. The parallel distribution of veins of quartz and iron pyrites was noted, and some interesting pieces of quartz grit with iron pyrites as cement were collected.

From Ynys Towyn we crossed the town to the little dolerite quarry on the Borth Road under Morfa Lodge. There a clean-cut section is exposed, and the contact phenomena of a 30- $\mathrm{ft}$. sill of dolerite were observed. This dolerite being later than the cleavage, has baked out the cleavage from some few feet of the rock with which it is in contact, but has not removed the large-scale distortional effects of the cleavage stresses. The contact rock is a compact hornstone which flakes along the bedding planes, and its occasional joints are parallel to the obliterated cleavage. The only new-formed mineral evident in hand specimens is pyrites, which occurs in striated cubes up to about half an inch across, along a band about half a yard below the surface of contact.

The next section visited was that of the old quarries and wharves along the west side of the harbour. This section begins in the upper part of the Portmadoc or Asaphellus flags, and is Proc. Geol. Assoc., Vol. XXIII, Part 4, I9I2.] 
continuous down to the horizon of Dictyonema. Ashy bands, cone-in-cone concretions of iron carbonate, and the curious rippled character of joint surfaces where the rocks are not quite homogeneous, were the features which received most attention. The mode of occurrence of the type of jointing known as needle cleavage was observed, and the difficulties of its interpretation appreciated. At the end of the wharves the footpath to Borth was taken and Craig-y-Don visited. Here the Niobe beds are exposed below the Dictyonema band, and in times past have yielded characteristic fossils, but beyond a few Obolus and Acrotreta there was little to carry away on this occasion.

Crossing the unexposed area of Dolgelly Beds which have determined the inlet of Borth Harbour, we stopped for lunch upon the outcrop of the Lingrulella band of the Ffestiniog Beds, and bags were replenished with slabs studded with Linsulellat davisii, the name fossil of the series. 'The great boulder of Snowdonian agglomerate, "Careg-wen," perched upon the top of the hill, was visited.

After lunch the party made its way across the upturned edges of the grits and flags of the Ffestiniog Series to the shore at Gareg Güch, and below Borth Fechan studied a fine example of "hassock" * bedding in one of the lowest of the thick "ringers" there exposed (Plate 26.A). The sills of pre-cleavage dolerite were examined at Gareg Gôch and Gareg Cnwc, and the differences between them and the post-cleavage sill mentioned above were noted. The chemical composition of the two sets of dolerite is almost identical.

At Fechan Point the more venturesome of the party did a little rock climbing along the water's edge, and were rewarded by an opportunity of studying the early stages in the development of the caves. Along this coast, which is abnormal in the relative importance of sand-blast and water-erosion, caves seem always to be determined and initiated by the work of wind-borne sand. The sand-blast meeting a wave-cleaned surface of Lingula Flags erodes somewhat curiously. The bands of ashy or gritty material behave variously. According to the stage of crystallization of the cementing quartz, they stand out as ribs or are etched into recessive furrows. Joints, if open, are further widened, but generally there has been a leeching of the cementing material towards the joint and a skin of rock more than ordinarily resistant to wind-erosion covers each joint-block, and delays the early stages of the widening process. Certain joints, usually occurring in pairs, more or less parallel, and only a foot or two apart, have not developed the skin (Plate 27.A). These are not open joints, they are, in fact, so little open, that even in a slate quarry they may not be detected until the quarried blocks come to be split; but where they cross the pre-existing bedding

* This is the "curled bedding" of the Quart. Joum. Geol. Soc., vol. lxvi (19ro), p. r 50. 


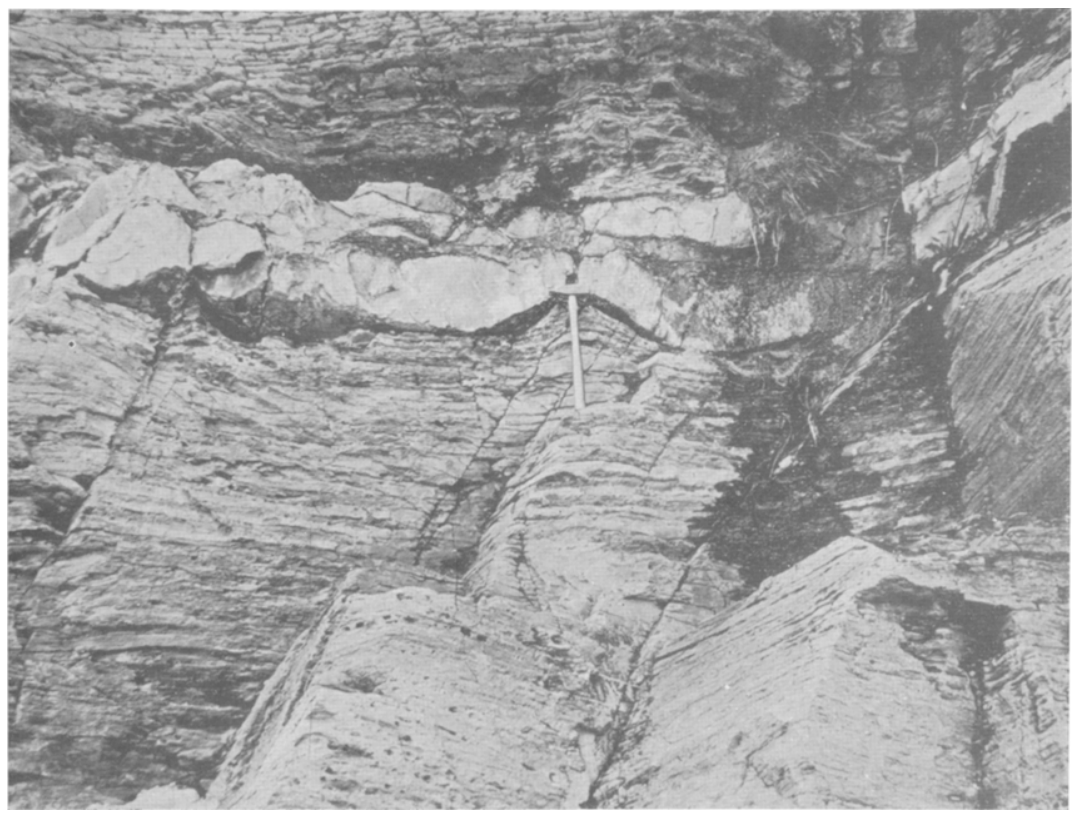

[Photo by E. C. Mlartin.

A.--Hassock Bedung, Fifestiniog Beds, between Gareg Góch and CAREg CNWC.

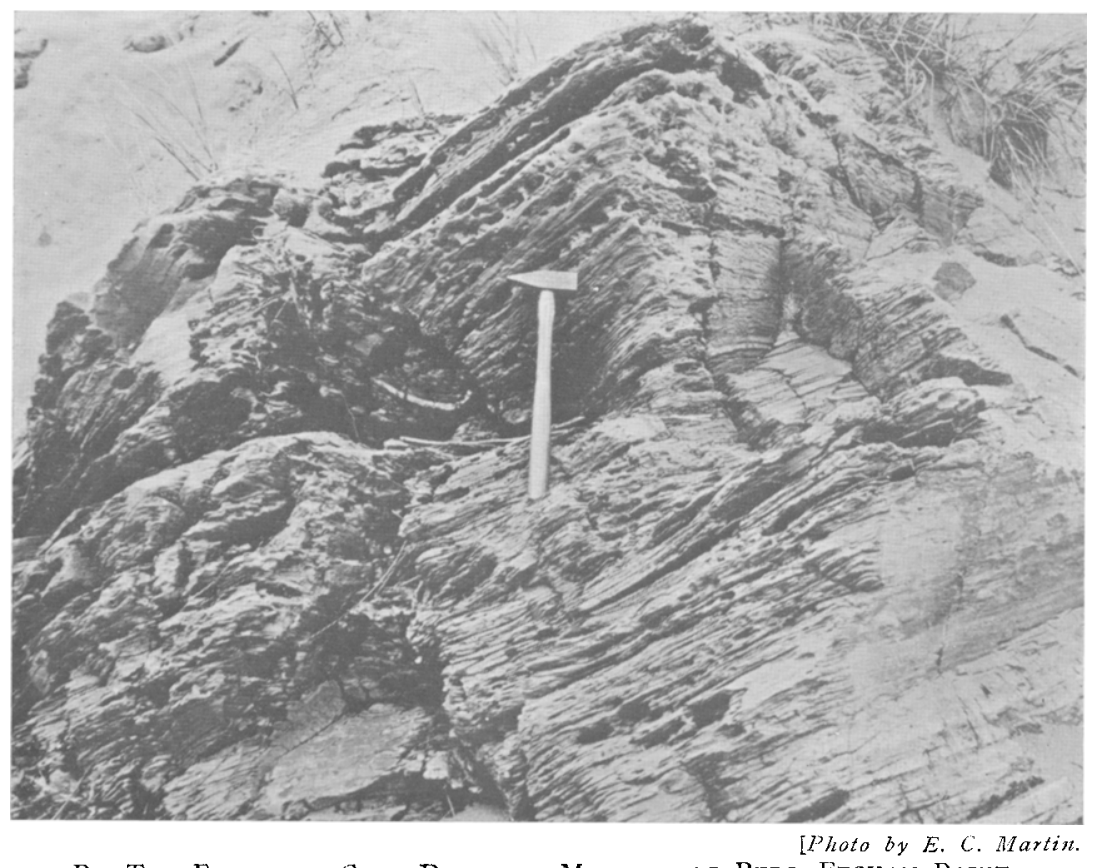

B.-The Effect of Sand-Blast on Maentwrog Beds, Fechan Point. 
and cleavage planes, these structures may change their directions and gape slightly at the crossings. Similar paired joints, probably also recent in origin, have been termed "posts" by the miners at Ffestiniog, and along this coast it is such "posts" which, eaten out into hollows by the sand-blast, eventually become sea-caves (Plate 27.B).

Where rock masses have been long exposed to the sand-blast, the skin of harder material is first worn through in the middle of the face of the joint-block, and as time goes on the softer material inside the block is gnawed out and a more or less complete boxstone results. In the Maentwrog beds the slaty bands have accepted a cleavage rather of the needle type. In these rocks many minor joints follow this cleavage, and packed needles, each with its skin, now make up the rock. Open master-joints determining rock faces cut the needles almost at right angles, and where such faces meet the sand-blast the rock becomes fretted most fantastically, and the truncated needles are eaten into cavities of about the size and shape of finger-stalls (Plate 26.8).

The shifting sands of the right bank of the Glaslyn estuary were then noticed and a visit paid to the oldest rocks of the district, which stand up through the Morfa at Ynys Cyngar. The spring storms had left open many fine faces of these Lower Maentwrog rocks, but the party was not able to obtain any fossil more characteristic than masses of worm tracks.

Returning across the sand-dunes we examined the cliff margin of the Morfa, and scrambled up to observe the displacement of the outcrop of pre-cleavage Dolerite produced by the Llanerch fault (see below). Descending at Capel Siloam we followed the road across the salt-marsh to Pont Morfa-bychan, and following round the hill to Ffynnon Ochr-cefn picked over the scree material for Maentwrog trilobites. In this scree slabs which are kept scoured by the sand-blast have occasional specimens of Agnostus and Olenus on their surfaces. Only rarely are these specimens worthy of specific determination, and it was great luck that the best specimen of Olenus truncatus yet found in Carnarvonshire was collected on this occasion.

At Trip the Excursion Secretary had arranged a sumptuous tea, which was laid out in the open. After tea we descended to the shore and examined the famous Black Rock caves, which have been eaten out along joints or bedding planes among the Upper Maentwrog Beds.

As at Fechan Point, the caves seem to follow "posts" rather than master-joints, but the largest of the Black Rock caves are due to the removal of the well-jointed sills and shattered dykes of the pre-cleavage dolerite. In the low evening light the colour banding of the alternating coarse and fine sediment in the Maentwrog rocks was well seen, but the greatest interest was aroused by the apparently impossible position of the ribs of a 
ship which have become jammed in a cleft between the main cliff and a stack.

We returned to Criccieth by way of the railway line.

APRIL 6TH.

This day was devoted to the examination of the Penmorfa fault. Trains being untrustworthy we again took carriages and drove to Portmadoc. Arrived at the Cambrian Railway Station we examined the augen shale of Ynys Calch, but failing to find fossils therein we soon left this for the more prolific rocks of Pen Syflog. Here Climacograptus scharenbergi and Dicellograptus sextans were turned out in swarms, and the method of their bending round the augens of ironstone was noted. The hunt for Angelini in the Tremadoc Rocks beyond the fault was less successful, but the change of lithology on crossing the fault was evident to all. Proceeding towards Tremadoc a halt was called at Hen Fynwent, where in a field just south of the site of the Roman hypocaust one of the minor thrusts of the Penmorla fault is exposed in a small section and has thrust back the stratification of the rocks of its sole, as shown in the photograph (Plate 28.B).

Following the old railway track, we visited the Tremadoc Iron Mine, and in collecting pieces of the pisolitic pyrites which have been left in the mine we were able to make out that the mined masses had occurred in lenses or boat-shaped augens elongate along the direction of dip. From the adjoining shales a few indeterminable graptolites were also obtained. A mass of vein-stone consisting of well-formed quartz, chalybite and dolomite crystals was broken up and distributed. West of the mine the party scrambled up to the outcrop of the thick mass of vesicular andesite and its overlying agglomerate which forms a sort of undercliff to the great escarpment of the Dolerite of Craig-y-Castell. Having obtained specimens of these rocks some of the party descended again to the road, but the more energetic ones followed the contour of the hill as far as the old Penmorfa Slab Quarry. The distance is only 300 yards, but the going is over the lichen-covered blocks of a giant scree of the dolerite, and the time taken was considerable. At the slab quarry a halt for lunch was called.

After lunch specimens of spilosites and adinoles were collected, and it was noted that at this locality all the fine-grained and flinty adinoles occur as thin bands among a mass of coarse volcanic ash. Continuing by the footpath up the hill, we examined the passage from spilosite into the drab hornstones (which, unlike the adinole, retain evident bedding planes) which adjoin the dolerite. We found the actual surface of contact and observed the gradual increase of the size of the felspar crystals and augite grains as one passes farther into the dolerite mass. Specimens of a variety of dolerite which contains hypersthene 


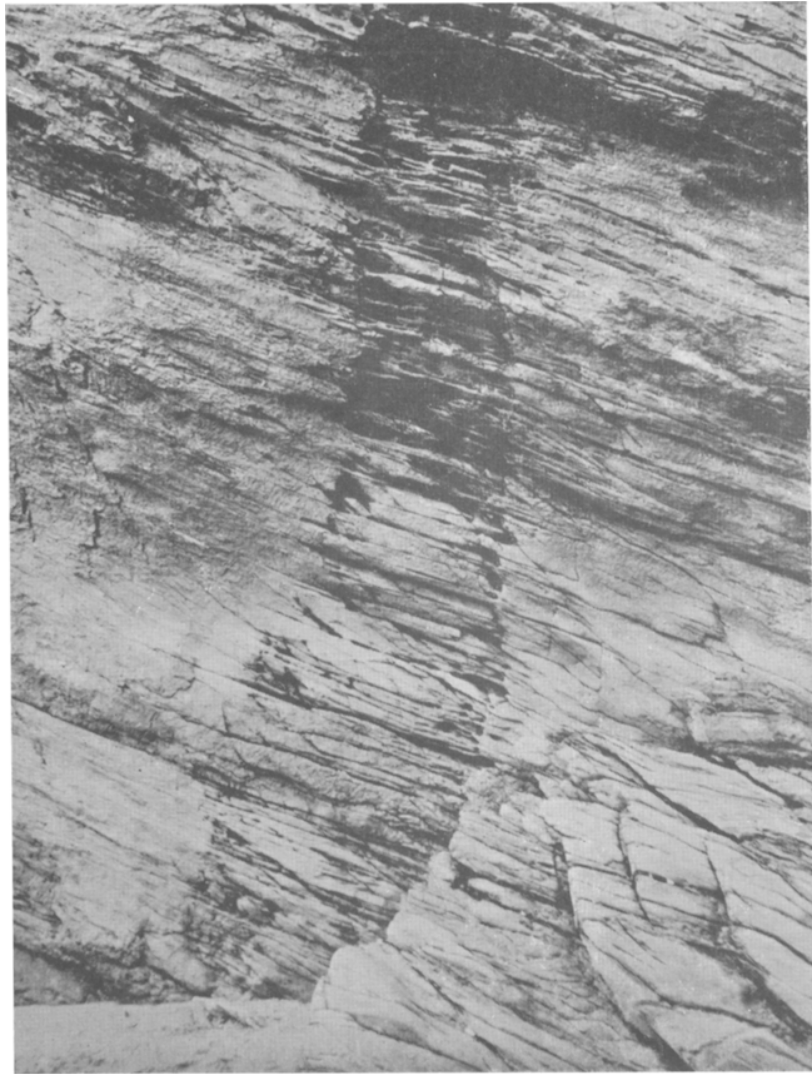

[Photo by E. C. Martin

A.- "Caves in the Making" (Stage 1), Fechan Point,

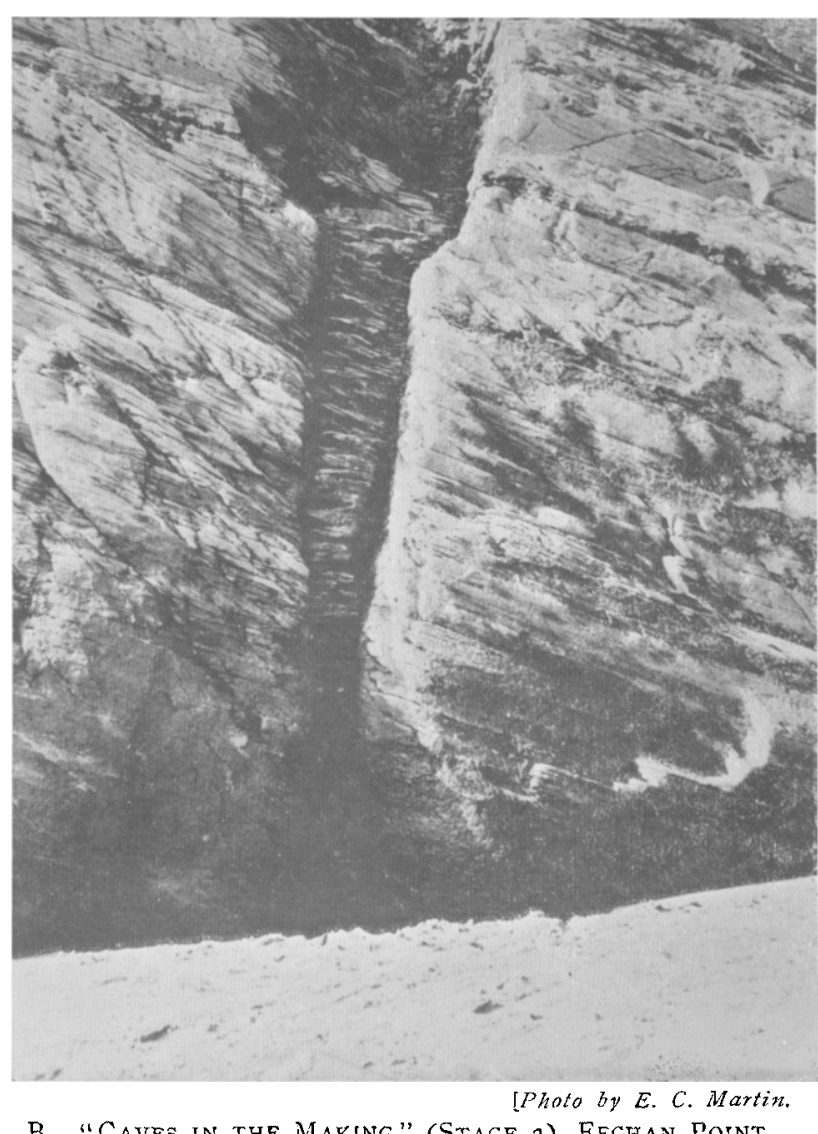

B.- "Caves in the Making" (Stage 2), Fechan Point. 
were collected just under the ridge of $\mathrm{Yr}$ Allt Wen, and white stringer veins of a variety with quartz-oligoclase-eutectic were also examined. Turning west we descended to the depression in which Beudyrgarth lies, and having there found the moorland exposures of the volcanic series, climbed out of it up the ice-worn back of Craig-y-Gesail to the top of that hill ( $89 \mathrm{I} \mathrm{ft}$.). This hill is a great roche moutonnée surfaced on the stoss side with the baked slates which overlie the lower sill of dolerite, and is liberally sprinkled with huge perched boulders brought by the ice from Moel-ddû and Snowdon. A fine view of the course of the old glacier and of the surrounding snowclad hills was obtained.

From the hill-top the direct route towards Tyddyn-dicwm was taken, it being accepted that the phenomena of metamorphism are the same here as adjoining the higher dolerite, at the flag quarry already visited. The next halt was made at the graptoliteyielding exposures for which Tyddyn-dicwm has so long been famous. The association of the graptolites with rocks containing lens-like masses of pisolitic iron ore was again noticed, and some ten or twelve of the well-known species of graptolites were obtained. The waste from trenches excavated for the Director when he was seeking to locate the Penmorfa fault, proved prolific in graptolites, but only traces of trilobites could be found in the Tremadoc beds where these adjoin. In the fields below Tyddyn-dicwm-isaf a hunt was made for the Shumqrdia band, but the only specimen of Shumardia obtained was from a loose block. In Penmorfa village street an Asaphellus was obtained from the old locality, and several nice specimens were got from the foundations of one of the cottages, but this very rich locality for the Shumardia or Shineton zone of the Tremadoc series is now really worked out.

From Penmorfa we were conducted by Mr. and Mrs. R. M. Greaves to their house at Wern, where we were very generously provided with a most welcome tea, and had an opportunity to walk through their woodland garden, with its wonderlul profusion of spring flowers just at their best.

After tea the party walked back to Criccieth by the road.

\section{APRIL 7TH.}

This day opened wet and there was no official excursion. About noon, as the rain had moderated, a party of enthusiasts decided to venture out and started north to visit the upper valley of the Dwyfawr. The first part of the way was over the boulderclay country just north of Criccieth, and the famous cromlech of Ystwm Cuddeidig was visited. About this time the rain ceased, and in. better weather the party examined the Snowdonian rhyolites which form the hill between the cromlech and Dolbenmaen. The steep-sided headless valley down which the upper Dwyfawr from Llanfihangel seems once to have flowed, called 
for much comment, and the Director's explanation of the beheading as being due to ponding along the margin of the Carnarvon Bay lobe of the Irish Sea Ice, seemed to be eventually accepted.

At Dolbenmaen the Tomen was visited and proved a fine view-point from which to inspect the overflow-channel through which the river still runs. Thence the road to Llanfihangel-yPennant along the main valley was followed, and it was seen how little the lower reaches of this valley have been sculptured by the ice.

From Dolbenmaen to Hendre-fach overlapping spurs are great features of this picturesque valley. From Hendre-fach to the head of the valley the spurs are so truncated that when mist covers the tops they can no longer be seen. It was thus when our party reached Hendre-fach, and the change in the type of scenery was most striking.

The explanation offered is that before a glacier had grown in the Upper Pennant valley the Irish Sea Ice had occupied the lowland and extended inshore about as far as Dolbenmaen. The advancing Pennant glacier had therefore to find egress over the already accumulated foreign ice, and in its erosion was compelled to adopt a base-level some $300 \mathrm{ft}$. above sealevel. Below this level the overlapping spurs due to riversculpture have been allowed to remain; but above it the valley has taken a U-shaped section, and at about $\mathrm{I}, 000 \mathrm{ft}$. the smaller tributary valleys "hang" upon its sides.

Close to the bridge leading to Careg Wen farm a fine selection of Didymograptus geminus preserved in relief was collected. The return route was by way of the old Moelfre slate workings and thence through rain and mist to Brynkir and by the road to Criccieth.

\section{APRIL. $8 \mathrm{TH}$.}

This morning was unfortunately also wet, and it was decided to take the Llanystumdwy excursion. The road across the spread of western Boulder Clay was followed to Rhyd-y-Benllig bridge, and the party turned down the right bank of the Dwyfawr. Vegetation was very wet and the examination of the black shales alternating with rhyolites opposite Coed Trefan was difficult, but in the flinty ashes exposed in the north-and-southranging reach of the river, some 300 yards east of Dynana, some hitherto unnoticed Orthis and Leptena shells were discovered. The specimens collected were rather inferior in their preservation and none of them are specifically determinable. They probably belong to a low horizon among volcanic rocks which are thought to belong to the Snowdonian series.

The steep walls of the open gorge between Dynana and Trefan were examined under better conditions, and the rhyolites and flinty ashes were seen to dip under the non-compact, coarse 
calcareous agglomerates which form the bank on which Dynana is built. Tufa deposited where water trickles out of the joints traversing this agglomerate was noticed, and it was suggested that the cave-like hollows at the base of the cliff-wall may be due to the crumbling of the rock after the calcareous cement.has been dissolved away to form such tufa. Certain hard masses occurring near the top of the agglomerate belt are covered with a strange dark brown earthy crust, and on breaking into these it was discovered that they are nodules, rudely septarian, in which the concretionary substance is carbonate of manganese. While sheltering during a rain-storm, Dr. H. Lapworth hammered at the band of shattered mudstone which overlies the agglomerate and brought to light several fragments of brachiopod shells and graptolites. The graptolites obtained resemble the starved types of Climacograptus which characterise the highest part of the Hartfell shales, but are not well enough preserved to determine the horizon exactly. Along the cart-road which leads out of the gorge to Dynana farm more hammering was done, and many of the mudstone bands were proved to contain fragments of fossils. A good tail of a Cybele vernucosa, and many pieces of Trinucleus cf. seticornis were got from a calcareous band on the western side of the track, but no real evidence of the exact age of the mudstone series was forthcoming.

Descending westward through the wood we came to the exposure of the Llandovery rocks for which the locality is notable. 'The exposure begins some few feet below the zone of Monograptus fimbriatus, but no fauna sufficient to determine the Dimorphograptus or Orthograptus modestus-zone has yet been collected. The $M$. fimbriatus-zone is well represented by some two feet of soapy black pyritous mudstone, very rich in graptolites all preserved in pyrites. The $M$. argenteus-zone overlies it, and, except for a pale streak in its midst, is of similar lithology. This zone is about two feet thick. Five or six feet of streaky mudstone with few graptolites follow, and in the midst bands of calcaréous. nodules occur, from which Phacops elegans has been collected. A four-inch band with the rich graptolite fauna of the $M$. convolutus-zone, overlain by grey mudstones, tops the eastern half of the exposure. Having worked the succession thus far, a halt for lunch was called.

After lunch the party scrambled quickly over the mudstones of the barren Cephalograptus and Monograptus sedguickii-zones. and ascended the cliff by way of a convenient tree. Upon the richly fossiliferous zone of Monograptus turriculatus of the Tarannon we settled down again, and many beautiful specimens of $M$. turriculatus, $M$. densus, $M$. nudus, $M$. proteus, $M$. runcinatus, and of the magnificent Petalograptus ultimus were collected. A few graptolites, including $M$. decipiens, $M$. exiguus, $M$. priodon, $M$. revolutus, were got from the overlying zone. 
Leaving the incised gorge of the Dwyfawr river just below this exposure, we crossed the boulder-clay plateau by way of Tyddyn Madyn Côch and Tyddyn Gwyn and descended into the similar gorge of the Dwyfach at the Factory Bridge near Bettwsfawr.

By kind permission of Sir Hugh Ellis-Nanney we entered the covert on the left bank of the river and examined the Bala rncks there exposed. The lowest rocks seen were the sooty black shales with teeming millions of Orthograptus truncatus, remains of which are abundant enough to make up a large percentage of the material of which some of the beds are composed. These black beds were at one time here prospected for coal. For about fifteen feet above the Orthograptus truncatus beds the sediments continue black and rich in ill-preserved graptolites. Dicellograptus morrisi is the characteristic form, but an undeternined species of Climacograptus is more abundant. Then the colour of the rocks changes from black to blue and no more graptolites are found. In their stead comes in a goodly crowd of trilobites and brachiopods. Trinucleus concentricus, Ampyx nudus, Cybele verrucosus, Agnostus trinodus, Calymene senaria and the large Asaphus powisii were collected on this occasion. Fossils are only abundant in the lowest beds of the blue mudstone series, and though there are miles of exposures of similar shales along the upper reaches of the Dwyfach, anly Plectambonites sericen and a few Orthis have been collected therefrom. Crossing the river we turned along its right bank and entered the Plas Hen covert. In this wood rhyolites alternate with flinty ashes containing bands of calcareous tuff rich in shelly fossils. The fossils, of which Trinucleus sp. and Lichas laxatus are the most characteristic, seem to point to a horizon near the top of the Caradocian, but the relations of this volcanic group to the Orthograptus shales are not evident.

Leaving the Dwyfach we turned up the Plas Hen stream. This stream shows a good exposure of a lower member of the rhyolitic series, here a coarse-textured ash, which, about half-way up to the smithy, is overlain by calcareous shales and impure limestones containing beautiful uncrushed specimens of an Orthis like Orthis alternata, and of a Nidulites. A large horny Lingula is also abundant, and a Calymene has been found, but all these have a wide distribution in time, and the horizon represented remains obscure.

Following the drive through the grounds of Plas Hen, we collected the fine fresh rhyolite which is spasmodically worked for road metal, near Pont Rhyd-y-Croesau. Some specimens of a rock from this locality have been shown to contain riebeckite, but the actual band of rock has not been recognised in situ.

A walk of a mile brought us to Llanystumdwy, where an indifferent tea was obtained, after which a visit was paid to the roadside exposure on the hill just north of the church, and fine 
specimens of Monograptus marri, $M$. crispus, and $M$. discus were obtained from the base of the thin grit bands which there occur among the shales of the Tarannon.

The return to Criccieth was by the footpath along the low sea cliffs of boulder-clay.

\section{APRIL 9TII.}

Before starting on this day's work the party took advantage of the fine morning and walked up to the castle to enjoy the view. The hills down to $\mathrm{I}, 000 \mathrm{ft}$. were sprinkled with melting snow and the higher tops were completely snow-covered. From St. Tudwal's by the Rivals to Snowdon, and from Snowdon through Hebog, the Moelwyns, Arenig, the Harlech hills and Cader Idris to the headland beyond Towyn, the panorama was beautiful and complete and was much admired.

Soon the arrival of carriages compelled us to descend and we drove to Portmadoc. Dismounting at Tuhwnt-ir-bwlch quarry, we examined that famous section, and, paying particular attention to the highest beds exposed, were able to collect several rather distorted specimens of Asaphellus homfrayi and of Hyolithellus or Theca. The present quarry workers have found that the rocks in the deeper part of the quarry are harder and more useful for building purposes than these fossiliferous beds, and Tuhwnt-irbwlch, as a fossil locality, is no longer what it was. The rocks now quarried are evidently within the zone of metamorphism of some igneous rock, and in certain beds have taken on a spotted appearance. The cleavage of the rock is well-nigh destroyed, and as the jointing is very regular, fine large slabs of rock can be removed.

Leaving the quarry we took the old footpath up to the disused dolerite quarry which forms so unsightly a scar on the north face of Moel-y-Gest. At one time some scores of men were engaged at this quarry, but it is not now worked, partly by reason of the toughness of the rock and the arrangement of its joints, and partly because of the cost of bringing the rock to market. The rock quarried is one of the post-cleavage sills of dolerite, and in its petrological characters it is typical of the dolerites of the district. Near the edges it is almost andesitic in texture, but towards the middle the ophitic plates of augite may be an inch or more across. In general it is nonporphyritic. Stringers of a white-weathering, fine-grained aplite traverse the coarse-grained parts of sill irregularly and in many directions, and in the same part of the sill there are pegmatitelike segregations consisting of felspar and augite with some zeolite and chlorite. Though its silica percentage falls just below $5 \circ$, the rock has no olivine in its composition.

From the quarry the party ascended to the ridge of the hill and proceeded along it as far as the western summit of Moel-y- 
Gest $(86 \mathrm{r} \mathrm{ft}$ ). A boisterous wind interfered with the comfort of some of the party, but the views over Tremadoc and the thrustplane country to the north, to Moel Hebog, the snow-covered Snowdon and the Moelwyns more than recompensed us for our trouble (Plate 28, A). Descending the escarpment of the sill we inspected the baked flaggy rocks upon which it rests. A hundred feet or so down the slope we picked up the line of the Dictyonema band, and having found it, halted for lunch and to enjoy the view southward over the sunlit hills of Harlech.

After lunch the outcrop of the band with Dictyonema was traced eastwards to the point at which it is truncated by the Llanerch fault. The Llanerch fault was next investigated, and it was eventually conceded, even by the sceptics, that this fault must be older than the Moel-y-Gest sill of dolerite, which it does not cut. Descending on the east side of the fault, we visited the old slab quarry above Tyddyn-llwyn, and from the dolerite exposed in the field above this quarry were able to collect pieces of an unusual variety of fine-grained dolerite, which contains spongy and much-absorbed porphyritic crystals of plagioclase felspar.

Descending almost to sea-level we turned south and visited a little cliff section behind Lletty in which bedding planes with Dictyonema are exposed. This locality being on the eastern side of the Llanerch fault gives us the measure of the vertical throw of the fault, which, on this and other evidence, is believed to be between 400 and $600 \mathrm{ft}$. The line of the outcrop of Dictyonem was followed up to the fault at Llanerch farm, and on crossing there to the west side of the fault, Ffestiniog davisii were met with immediately. The outcrop of the Lingulella band was followed by Beudy Pencerbi to the top of the ridge, and we noted the wild moorland character of its outcrop. Thence to Bron-y-foel our way lay through the more fertilehollow, determined by the soft black slates of the Dolgelly group. At Bron-y-foel we stopped a while to see the old slate quarry, which was worked in these rocks before Blaenau Ffestiniog had been heard of. For fifty years the quarry has been disused, and it is difficult now to see why slate-working was ever started at this place. Leaving the old quarry we followed the cart-track down to Cefn Cyfannedd, noting in passing the spot at which the Dictyonema band is exposed in the road. At the bend of the road to the last-named farm the wall was victimised, and many were the fine slabs of Dictyonema socinle which, by kind permission of Mr. Greaves, we carried away. From the spoiling of the wall at Cefn Cyfannedd we proceeded to Wern, where, for the second time on this excursion, we were most hospitably entertained to tea by Mr. and Mrs. R. M. Greaves. By reason of over-exertion in accompanying us over the Penmorfa rocks on April 6th, Mr. Greaves was unfortunately confined to his bed, and 
Proc. Grol. Assoc, vol. XXIII.

PIATE 28.

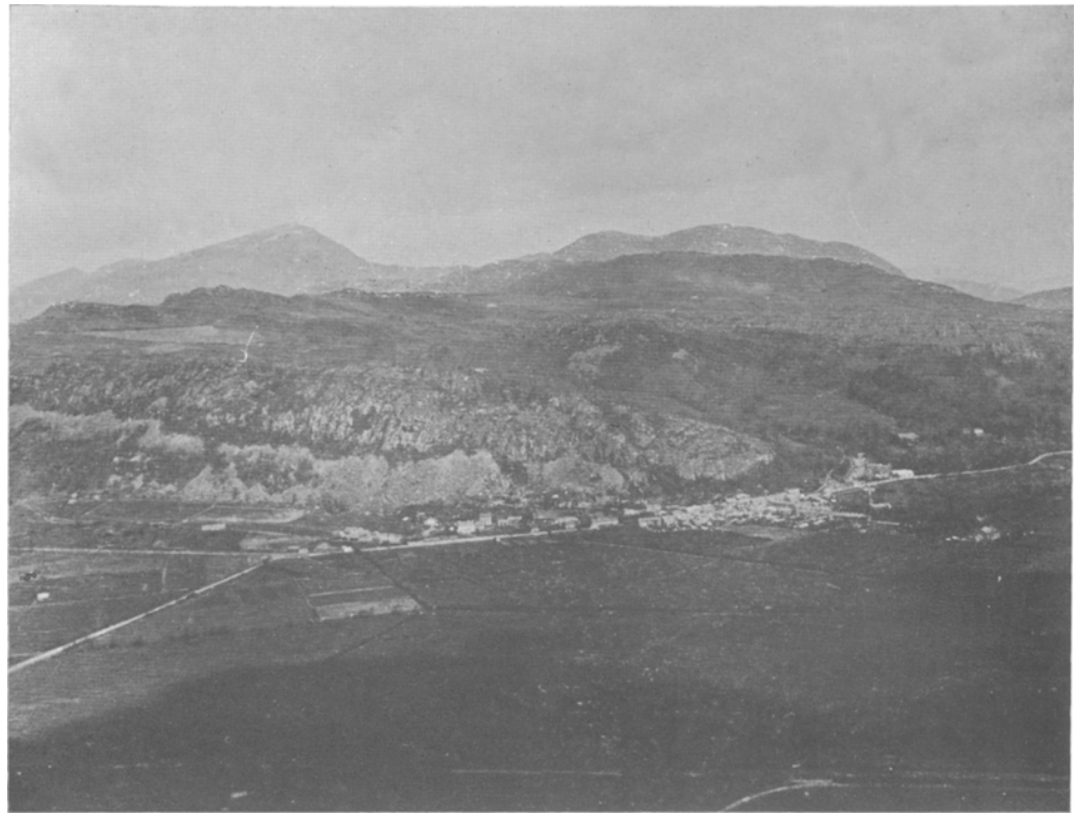

[FHoto by E. C. Martint.

A.-View from the Dolertte QIjakry of Moel-r-Gest, LoOking North. Shows the successive escarpments north of the Penmorfa Fault. The village is Tremadoc, the distant hills Moel Hebog and Moel Ditû.

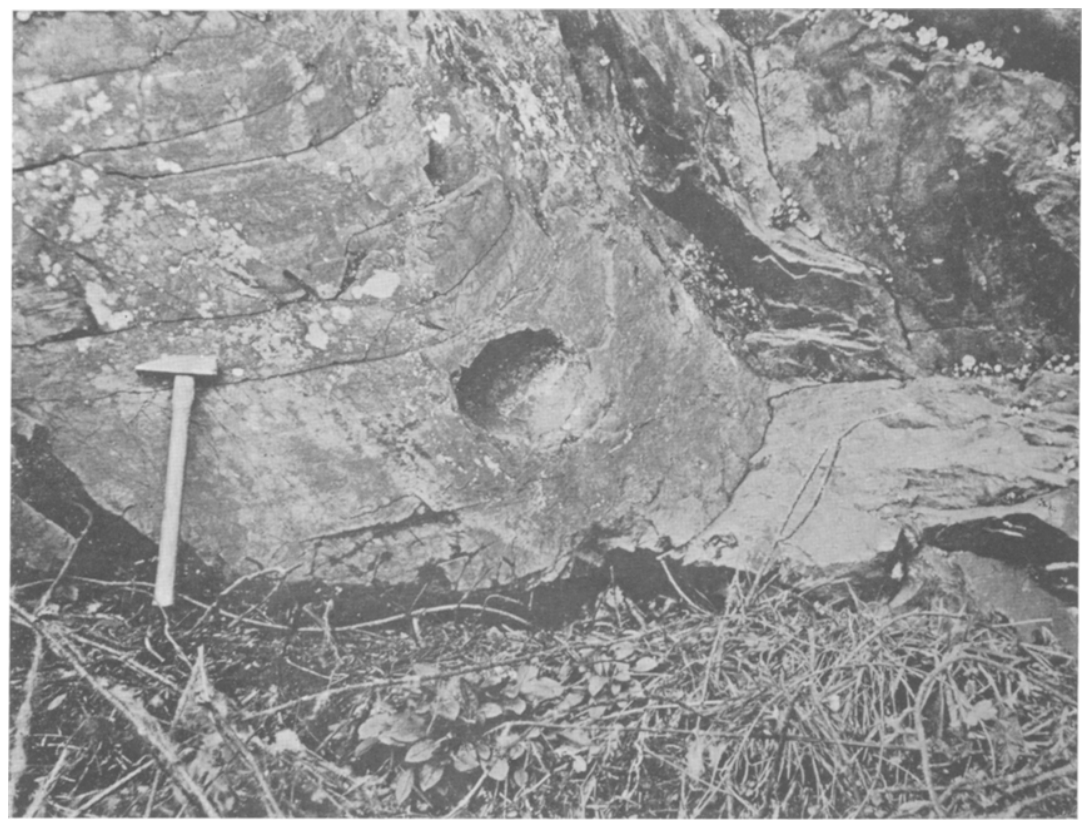

[Photo by E. C. Martith.

B.-Thrust-Plane Subsidiany to the Pennorfa Fault, South of Hen Fynwent, Trematoc. 
on this occasion Mrs. Greaves had to fulfil the duties of both host and hostess.

While we were at tea, rain began to fall, and by the time we reached the great slab quarry worked by the Cambrian Railway Company just west of the gates of Wern, the rain was so umpleasantly heavy that the excursion had to be cut short, and most of the party made their best pace home. A few, however, remained behind to see the quarry, and were rewarded by finding the tracks, sun-cracks, and ripple-marks which cover the faces of the slabs of these Ffestiniog beds, shown up strongly by the film of water on their surfaces. A photograph of a very beautiful example of the type of "track" to which Salter gave the name Crugiana is reproduced (Plate 29). The specimen illustrated was collected from this quarry by Mr. Williams, the schoolmaster at Penmorfa, early this year, and was presented by him to the Director during the excursion. The tracks of the Crustacean, described by Salter in $185^{2}$, , came from some now unrecognisable locality in the immediate neighbourhood.

APRIL IOTH.

This day was devoted to the examination of the country immediately around Criccieth. The tide being favourable, we began at the cliff on the east side of the Castle Rock. The fresh rock is a blue or blue-grey felsite with a few porphyritic crystals of albite-oligoclase scattered through a micro-crystalline ground mass. Generally it is seen weathered to bright buff, yellow, or even pinkish red, which, without microscopic examination, appears just as hard and fresh as the blue-grcy rock. In this partly weathered material small differences in the compactness of the original rock are rendered conspicuous as colour bands, and have the arrangement which one associates with the flow of a viscous fluid. On this east side of the Castle the rock has a rude columnar jointing and the faces of the columns all pitch to the east ; it is thought that they afford evidence that the rock mass is a laccolite intruded among sediments which dip to the west.

Almost more interesting than the felsite of the Castle Rock is the drift exposure on its eastern side. Just under the pebbles of the beach as they lie at present is a wave-cut platform, and on this rests a lot of angular felsite rubble considerably weathered, and evidently fallen from the Castle Rock. This is the pre-Glacial " head." On it rests a mass of stony clay with rounded pebbles, of which the majority are local and a few are from the hills north of Criccieth. This stony clay forms the lowest $3 \mathrm{ft}$. of the cliff as far as the lifeboat house, and is characterised by having all its larger stones lying with long axes vertical. It is cut off sharply at the top (Plate $30 . \mathrm{A}$ ).

\footnotetext{
*Quart. Journ. Geol. Soc., vol. x, p. 2 to. See also Rep. Brit. Assoc., 1852.
} 
On the stony clay, close up to the Castle Rock, rests a further mass of angular head free from foreign stones, and on and in this occur lenticles of fine, well-sorted blown sand, free from stones. This sand extends some ten or twelve feet up the cliff, and, fingering out at several levels among the succeeding accumulation of Boulder Clay, extends about ten yards out from the cliff between the top of the lower stony clay and the Boulder Clay (Plate 30. B). The main face of the cliff consists of normal Boulder Clay with well-scratched stones, and may with some certainty be referred to the accumulations brought down by the local Welsh ice. Near the top of the cliff the clay becomes less compact and encloses wisps of material gathered from a water-worn beach, and then at the top is seen the second Boulder Clay, with large and well-worn boulders from the Western Lleyn.

Leaving this exposure we crossed the Esplanade and passed by Merllyn to examine the great moraine of the Irish Sea ice. This moraine, which marks the eastern limit of glacial accumulation in this district, consists of a very tough blue Boulder Clay, which, when attacked by the sea, falls away in compound masses often as big as a hay-wain, which for a time behave as boulders upon the beach. Fine-grained and compact in its ground-mass, its contained stones are always polished and generally scratched parallel to their greatest length. The commonest large boulders (and these are often masses many cubic yards in bulk) are of the coarse dolerites of the Dolbenmaen district, but all the tougher rocks of Western Snowdonia are present as large baulders, and with them occur many smaller masses from the Rivals and Western Lleyn. A pebble of the raebeckite rock, reputed from Ailsa Craig, and several granite masses of the Eskdale type, as well as jaspers from Aberdaron and carboniferous limestone from the Menai, were collected in situ by members of the Association. Discriminative erosion by waves washing away the clay matrix, and by the tidal drift screening off the pebbles as they become small enough, is well illustrated at this locality, and it was seen that the biggest boulders, being too large here to be moved by the sea, settle down where they lay in the moraine and have gradually formed a sort of submarine causeway, the line of which can be followed far out to sea.

From Merllyn we traced the margin of the drift area up to the hills. At Ceunant da we examined the gorge, cut evidently by a glacial overflow and now dry except for the sluice which has been diverted into it for the convenience of the owner of Pen Ystumllyn farm. At Gloddfa, the old slate quarry in which Criccieth stores a portion of its water-supply, we examined the actual margin of the drift, and concluded that the driftless country to the east is only free from drift because, during the latest stages of the ice retreat, that drift was washed away by the streams which coursed between the ice margin and the solid rock. 
Proc. Geol. $\Lambda$ ssoc. vol. XXIII.

Plate 29.

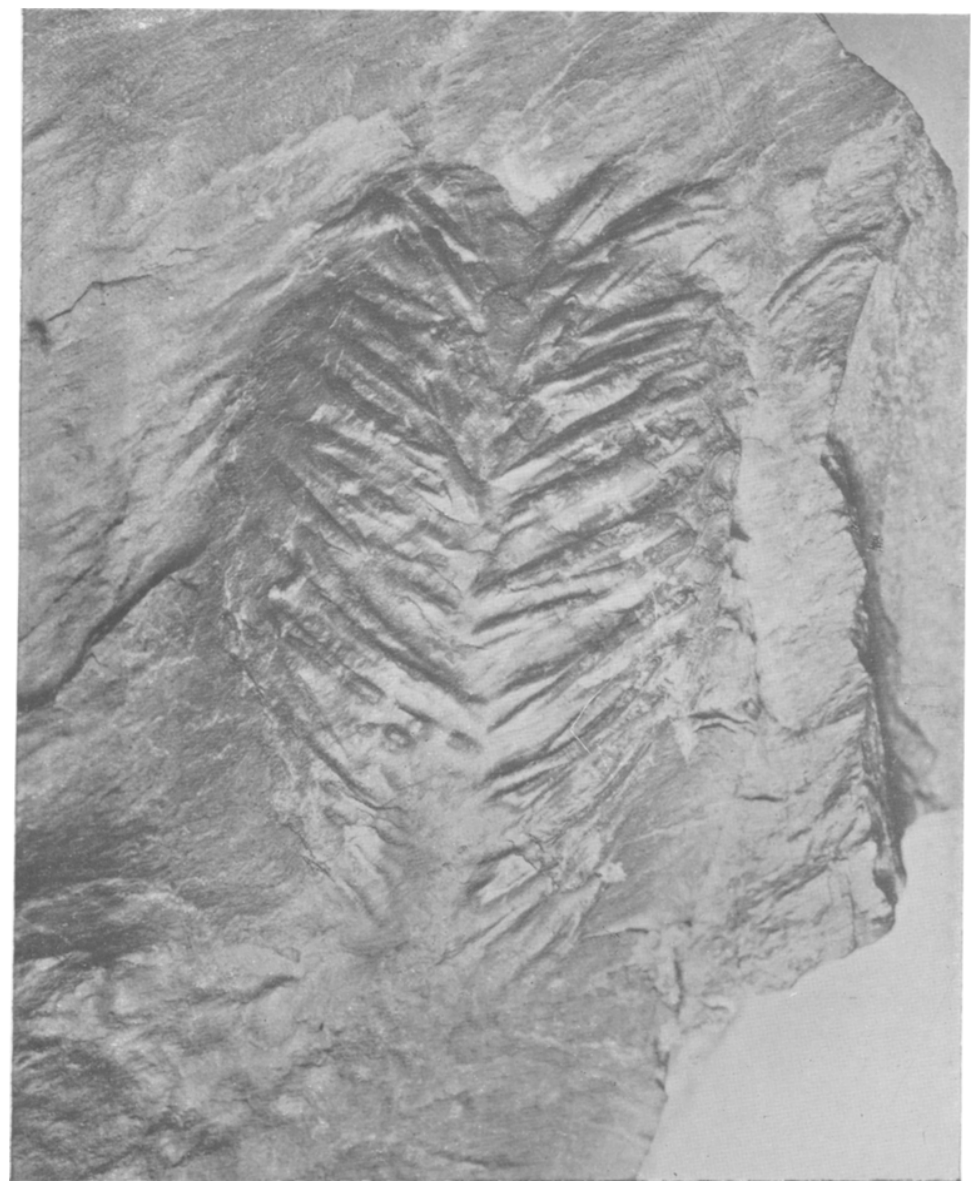

[Photo by W. Tams.

Cruziana semiplicata, Salter. Ffestiniog Beds, Cambrian Railway Quarry, Coed-Y-Chwavel, Wern, Portmadoc.

(Natural size.) 
The slate rocks exposed were hammered over for graptolites, and several much-distorted specimens of Climacograptus were handed to the Director for identification, but these provide no evidence of the exact horizon of the rock.

At Pen Mynydd dû, the little quarry in the basal Ordovician. grit was visited, and the crushed and augen-like form of the grit masses noted. The line of the tentacles of grit was then followed back to Pen Ystumllyn farm, and a number of cross-traverses made between this line and the band of grit, which in this district appears among the Asaphellus flags of the Tremadoc. The floor of a dry valley cut by a glacial overflow on the east side of Moel Bach provided a convenient place for lunch.

After lunch we crossed the outcrop of the Tremadoc rocks to Ogof ddu and examined in detail the exposures of the various. beds between the Dictyonema band and the Ffestiniog beds with Lingulella davisii. Excellent specimens of Agnostus trisectus, $A$. pisiformis, and Ctenopyge pecten were obtained by several members of the party, but as the details of this section have been recently described, $*$ it is unnecessary here to recapitulate.

After tea at the Marine Hotel, we turned our attention to boulder-hunting among the drift exposure above the sea-wall at the western end of the Marine Terrace. The drift section at this. locality is homologous with the higher part of the section exposed east of the Castle, which has already been described; but the intercalation of an irregular stratum of wave-worn beach pebbles is better seen. The upper mass of Boulder Clay has evidently been driven forward westward over the intermediate beach material, and has caused it to ruck up into folds, which at one point have taken the form of a breaking wave, and at several places have broken away along the middle limb into small thrust-planes.

A walk to the flagstaff on Mynydd Ednyfed to view the panorama of the hills in the evening light completed the day's excursion.

\section{APRIL IITH.}

Difficulties of transport having rendered the proposed excursion to Snowdon unfeasible, a supplementary excursion to the region of thrust-planes north of Tremadoc was arranged, and we drove to Tremadoc village. The cliffs behind the village are a part of the escarpment of the great dolerite sills, which form $\mathrm{Yr}$ Allt Wen, but just here the base of the escarpment has dipped below sea-level, and until the silting-up of the Morfa the cliff was washed by the sea. At that same time the upstanding rockmasses of Ynys Fadog, and Ynys-hir, which consist of Ordovician andesitic ashes and lavas, were islands in fact, as now in name.

A walk eastward along the main road took us by Tan-yrAllt to the outstanding peninsula known as the Roman Altar, which is determined by an outcrop of the resistant Ordovician

\footnotetext{
* Quart. Journ. Geol. Soc., vol. Ixvi (19ro), p. I53.
} 
volcanic rocks. The form of the outcrop is that of a laccolite augen, measuring 200 yards along the strike, but the rock exposed is all coarse agglomerate. A hot climb through the wood of Tan-yr-Allt, which is planted on a shale or slate outcrop devoid of exposures, brought us to the exposure of a second and smaller augen of equaliy coarse agglomerate. A steeper ascent through the top of the wood showed us the character of the scree from a third augen, which forms the hill-mass Y Glog. Halting for breath on the south side of the summit ridge, a fine exposure of agglomerate, with individual pieces of lava six inches or more across, was discovered. The Y Glog agglomerate outcrop is 500 yards long by about roo yards broad; we traversed it along its greatest length and examined its pinching out westwards at the col between Cwmbâch farm and Llyn Cwmbâch in some detail, and it was seen that at this end of the exposure the augen is compounded of several smaller augens. A little detached augen, only 20 yards long by 5 wide, which forms a swelling in the midst of the bare col, was next examined, and it was admitted that this augen is certainly surrounded by crushed slate or shale. The south-east end of the largest of all the augen, that of Y Fedw, almost a mile long and varying in width from 20 yds. to $60 \mathrm{yds}$. or $80 \mathrm{yds}$, was also examined, and it was evident that though these exposures of the volcanic rocks may be laccolite-like in form, they are really a not inconsiderable series of volcanic accumulations, which has been crushed and torn into augen-like masses by earth movements of the thrust-plane type.

When this was conceded, we crossed the hollow in which Llyn Cwmbâch lies, to the outcrop of the largest of all the dolerite masses of the district, that known as the Pant Ifan sill. Fine-grained rock was collected at the under-margin close down by the lake shore, and coarser and coarser rock was met with as we scrambled over the rugged moorland to the northward. When the centre of the sill was reached a halt was called, and energetic members broke their hammers while the rest of the party bad their lunch. The rock is very massive in its cuboidal or platy jointing, and is exceedingly tough. The master-joints strike east and west, and determine hollows which are filled with peat and bog.

After lunch, for the convenience of some of us who wished to catch an early train, the party divided. Some under. Mr. Hinton's guidance went to see what views were afforded by the mountains of Pen-yr-Allt and Moel ddú. The rest crossed the slate-rock hollow to the foot of Pen-yr-Allt and descended by the track to Fron Olen and the famous locality for Brookite at Prenteg.

The country rock at this locality, which adjoins the main road from Tremadoc to Beddgelert one and two-thirds miles from the 
Proc. Geol. Assoc, vol. XXIII.

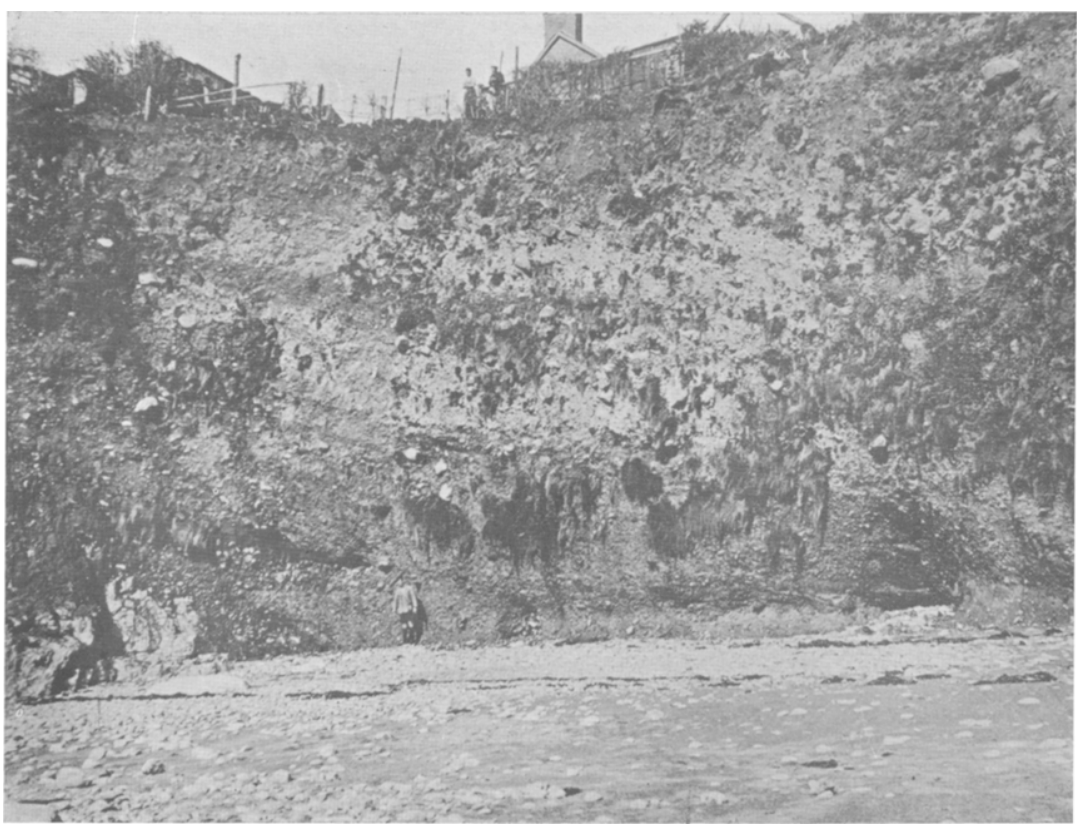

A.-Boulier Clay East of Criccieth Castle.

On the right the Boulder Clay rests upon Stony Clay with rounded pabbles. On the left upon the Felsite of the Castle rock. The rubble mass on the left of the picture is Head, and is shown in detail below.

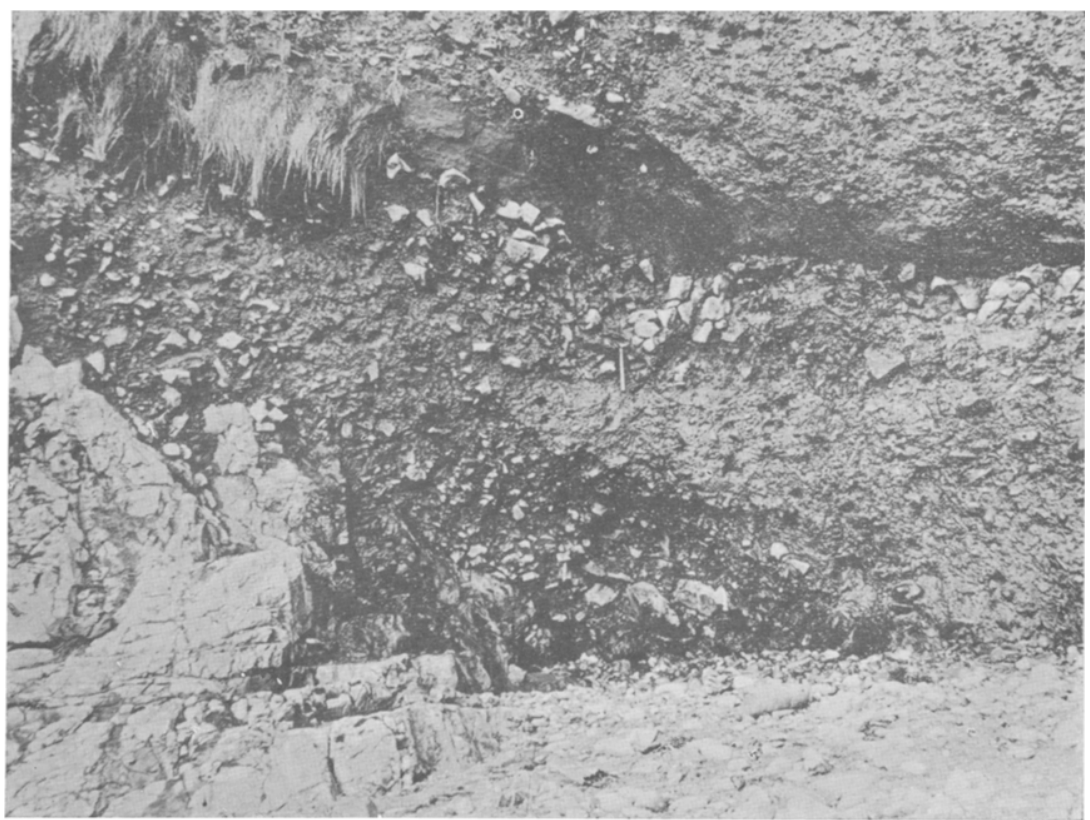

Lhoto by E. C. Martin.

\section{B.-Boulder Clay Resting upon Head, Base of Cliff East of Criccieth CASTI.E.}

The grass is growing on Blown Sand which intervenes between the Head and the Boulder Clay. The interdigitation of Head with the Lower Stony Clay is well shown about the middle of the picture. 
Tremadoc Market Cross, is a sill of dolerite quite similar to the dolerites of Moel-y-Gest, Tremadoc and Pant Ifan. At Prenteg the dolerite is intruded among slaty rocks which contain Trinucleus and a few brachiopod shells, and has baked these rocks at its contact with them almost to porcellanite. The dolerite exposed is not fresh ; it is, in fact, rather abnormal in this respect, and probably for this reason it was found out by the local road men, and is quarried and broken up by them for road-mending. Everywhere on the exposed face the dolerite is veined with ramifying quartz veins, which follow no regular system of jointing, but come off as branching and discontinuous strings from equally irregular but wider quartz-filled cracks or fissures. The wider quartz veins often fail to fill their fissures completely, and where this is the case, well-formed small crystals of quartz line the cavities, which may or may not have been filled with a later generation of crystalline carbonates.

Under the microscope the dolerite is found to have lost most of its original minerals, and though the form, texture and ophitic arrangement of the plagioclase and augite of a typical dolerite remain, there is little of these minerals now recognisable in the slices. Ilmenite, once abundant, is now wholly gone to leucoxene or something like it, and in a muddle of epidote granules, hornblende needles, calcite and chlorite plates, it is hard to make out the mineralogy of the rest. There is probably a good deal of secondary albite in the ground mass, and from the behaviour of slices which one has tried to clear in hydrochloric acid a good deal of some hydrated zeolite is suspected.

The Brookite occurs sometimes in the quartz veins, but more often as plates standing out from the surface of separation between veinstone and country-rock, and in certain minute veins of carbonate material which follow sealed joints in the rock among the veins of quartz. Wherever brookite occurs it is associated with beautifully formed crystals of pure albite, which consist of two (rarely more) individuals united according to the Albite law. These crystals of albite are almost completely bounded by crystal faces and only touch the wall of country-rock along one edge or side, and if the veinstone be calcite, are just as frequently wholly imbedded in the veinstone. The crystals of brookite are similarly placed, and as might be expected, are correspondingly difficult to collect.

The best specimens of brookite have, of late years, been obtained by special blastings from one of the bigger incompletelyfilled quartz veins exposed about the middle of the quarry face. Blocks of the carbonate-bearing quartz were taken away bodily and treated at leisure in a bath of dilute hydrochloric acid. A few large plates of brookite broken by the workman from the veinstone were distributed among the party, but our hunt among what was presumably similar material on the roadside heaps was 
unsuccessful. More entertaining proved the scramble along the top of the dolerite where, in an old excavation, the carbonates of the veinstone have been leached out, leaving joints more or less filled with a fine unctuous slime of hydrated limonite, out of which the crystals of brookite may be washed or sorted with forceps. The joints when newly opened have crystals of albite and brookite still adherent to the walls, but on exposure both these minerals disappear. On a joint-face left exposed since a certain excavation for Brookite, made by the Director in 1905 , there has appeared an incrustation of anatase in well-formed double quadrangular pyramids. Specimens of these were collected by the party. This joint-face continues downwards into an open joint, and in the hope of getting brookite crystals such as he found in Iyo5, the Director dug out some of the powdery débris contained therein. The débris proved to be gritty in texture and full of little striated cubes of pyrites, but the hunt for titaniumbearing minerals was without success. A portion of the side wali of the joint carried good octahedra of anatase which were in close apposition to plates of brookite. A piece of this side wall collected by Prof. Watts was handed by him to Mr. T. Hitchon of the Imperial College of Science and Technology, who furnished notes which have been incorporated in the description of the rock which is printed below.

On the field evidence, the Director has concluded that the anatase at this locality has formed during surface weathering and by the polymorphic inversion of brookite. The mode of formation of the brookite remains obscure, but it is clear that all the chemical constituents, except, perhaps, silica, water and carbon dioxide, of the brookite-bearing veins are present in the country-rock, and in not very different proportions. The making of the veins is not a process belonging to the present cycle of water circulation, but is rather to be referred to some epoch closely subsequent to the consolidation of the dolerite, and before the circulation of intratelluric waters along the joints of the cooling rock had ceased.

A walk by way of the Croesor railway took us to Portmadoc for tea and so on by train, road or footpath to Criccieth and the end of our Easter excursion.

\section{APPENDIX.}

Notes on the Petrology of the Decomposed Brookitebearing Rock of Prenteg, near Tremadoc, North Wales.

The colour of the rock examined is dirty white, and small brownish specks are developed through the whole mass. Brookite crystals and quartz crystals appear on the surface of what has evidently been an open crack. 
For the purpose of examination one piece of the rock was roughly powdered in a steel mortar, and the powder was subdivided according to the size of the grains by means of a nest of sieves. Each portion separated was washed in water, and, after being dried, was looked over with a hand lens and sorted with forceps.

From the coarser samples, well-formed crystals of quartz and of albite were thus picked out in quantity, and many fragments of Brookite and a few of anatase were also so obtained. Many of the particles, however, were found to be so coated with limonite or other iron oxide as to be unrecognisable; almost all the particles retained on the finer sieves were of this character.

After sorting by hand, the powders were each cleared by boiling with hydrochloric acid, but as after the operation only brookite, quartz, and partly decomposed felspar could be identified, these samples were set aside.

\section{Notes on the Minerals.}

Quartz.-The crystals are extremely clear and have the prism (Ioīo), and the rhombohedral faces (Ioì and oIì) well developed. Small diamond-shaped faces of the trigonal pyramid ( I I $\overline{\mathbf{z}}_{\mathbf{I}}$ ) were also clearly seen on several crystals.

Albite.-The albite crystals are exceedingly fresh and well formed, and are especially interesting. The basal plane (oor), the prisms ( $\mathrm{I} O$ and $\mathrm{I}$ io), the brachy-pinacoid (OIO), and the macrodome (ior) can be made out without difficulty. The crystals are colourless and transparent, and show a well-defined basal cleavage. The twinning is typical, being according to the Albite law.* A few examples of simple twins were found in which the angles between the intersecting cleavages, as seen through the brachypinacoid under the microscope, were measured as $53^{\circ} 45^{\prime}$ and $126^{\circ} 30^{\prime}$, and are therefore according to the Carlsbad law. Becke's method shows the refractive index of the crystals to be lower than that of Canada balsam. The extinction angle is positive, and, as the average of ten observations on the face oro, gave $20^{\circ} 10^{\prime}$. The optical sign is positive and the position of the interference figure is that of a typical crystal of albite.

Brookite. - The fragments of brookite contained in the powders were all portions of larger crystals, and as the habit seemed to be that usual to the locality they were not further examined. The colour of the fragments varied from a pale orange, through red, to a brown which is almost opaque.

Anatase.-The anatase crystals are yellowish in colour and are transparent. The habit is tabular, with faces developed around the edges of the plates. These marginal faces may be interpreted as being pyramids of first and second orders, but the evident parallel growth shown by some of the plates renders

* Mr. A. Hutchinson, in rgo5, determined the angle between the face oot on one part of the crystal, and oor on the complementary portion across the Albite twin plane, on a crystal from this locality, to be $7^{\circ} 19^{\prime}$.

Proc. Geol. Assoc., Vol. XXIII, Part 4, igl2.] 
this interpretation somewhat uncertain. The refractive index is very high. No cleavage was observed. The extinction is straight. The interference figure is uniaxial over parts of certain crystals, but in others, as indicated by the separation of the hyperbolas, slightly biaxial. This latter phenomenon may be due to imperfect parallelism in the parallel growth of associated crystals, and it is a noteworthy characteristic of crystals from several other localities.

One crystal of anatase was found which showed a considerable development of the planes of the unit pyramid. The faces of this crystal are striated parallel to their intersection with the basal plane, and the existence of a strong parting or cleavage parallel to the base is suggested. It may be that the tabular plates already discussed are themselves fragments of similar double pyramids which have been broken parallel to such cleavage or parting, but it was not possible to determine this for certain.

A second piece of the rock (the freshest obtainable) was examined by the method of thin slices. One slice was cut close to, and parallel with, the surface which carried the brookite crystals, and another was taken at right angles to this direction. By reason of the softness of the rock the slices were difficult to prepare and not very satisfactory when examined. The minerals recognised 'were the same in both of the slides, but it was noticed that alteration had not proceeded so far in the portion of rock which adjoined the brookite-bearing surface as in the part remote therefrom. Intrinsic evidence of the original igneous character of the rock is provided by the apatite prisms, and by the broad pattern of the ophitic structure with which plagioclase felspar and augite of the original dolerite intercrystallised. In the slice close to the brookite-bearing surface a mineral similar in its optical properties to augite, but without its cleavage, has pseudomorphed the augite fairly exactly, and a granular mixture of minerals has taken the place of the plagioclase. In the section at right angles, even the ophitic arrangement of the two sorts of alteration products is obscure. Leacoxene, which represents original ilmenite, is interesting, and instead of the local large plates and skeletal rods of the titaniferous iron oxides, appears in compound granular patches scattered throughout the rock. There is less leucoxene in the neighbourhood of the Brookite than elsewhere. Brookite appeared as a single elongate patch, which is too much broken and opaque for identification per se. Albite clusters round the Brookite in water-clear grains with characteristic twinning, and other similar granules can be made out elsewhere through the rock. Calcite is omnipresent in plates or patches, sometimes clear and sometimes enclosing and growing round other minerals. Quartz occurs in like manner, but is less abundant and contains fewer inclusions. Another colourless mineral is isotropic and has a very low refractive index. This often occurs in the midst of a patch of calcite and 
may be Analcite. There are also many large and small patches of a cloudy kaolin, or colourless chlorite substance, but these do not easily lend themselves to specific determination. Epidote granules are present but are not abundant.

\section{REPORT OF AN EXCURSION TO THE HITCHIN} AND STEVENAGE GAP.*

APRIL 27 TH, I9I 2.

Together with a General Account of the Features of the DISTRICT.

By William Hill, F.G.S., Director of the Excursion.

After a pleasant journey of a little less than an hour the party, numbering $3^{\mathrm{I}}$, arrived at Knebworth Station at about a quarter past two.

Leaving the station, they proceeded northward by the broad path along the western edge of the Knebworth railway cutting. Here, the Chalk (zone $M$. cor-testudinarium), much piped, is exposed. The Director drew attention to the fact that, at the southern end of the cutting near the station, some $15 \mathrm{ft}$. of brick earth was found banked against the Chalk when the railway was widened some years ago, and from this several Palæolithic implements were obtained.

Passing over the fine bridge of red brick which spans the railway with a single arch, the party found themselves on the Great North Road on ground of considerable elevation $(375 \mathrm{ft}$.), from which a wide general view of the country could be obtained. The Director pointed out that they were now on the southern side of that breach in the Chiltern Hills known as the Hitchin and Stevenage gap. This gap in its narrowest part, from the $400 \mathrm{ft}$. contour line on the west to that on the east, was about two miles wide: though the ground on the west rose to $500 \mathrm{ft}$. a very little way beyond this contour line, it did not reach that elevation on the east for some distance (see Plate $3 \mathrm{I}$ ).

The natural features within this gap were most interesting. They consisted of two valleys, one drawing to the southward, which he would call the Stevenage valley, with its drainage into the Thames, the other the Hitchin valley, drawing northwards, and draining into the basin of the Ouze. These valleys overlap for a mile and more, so that the watershed is a sinuous line running from Newton Wood (which was pointed out), through Stevenage, to the high land east of that town, on the slope of which Stevenage Church was visible.

The ground was seen to slope somewhat sharply to the

* With the account of this excursion is incorporated some new information in connection with the thickness of the deposits of drift in the Hitchin and Stevenage Valleys. 